\title{
Production of Quality Housing in Urban Transformation in Areas under Disaster Risk: Osmangazi and Yıldırım, Bursa, Turkey
}

\author{
Murat Taş, ${ }^{1}$ Nilüfer Taş, ${ }^{1}$ and Zehra Berna Aydın ${ }^{2}$ \\ ${ }^{1}$ Department of Architecture, Faculty of Architecture, Uludag University, Görükle Campus, Nilüfer, 16059 Bursa, Turkey \\ ${ }^{2}$ Department of Econometrics, Faculty of Economics and Administrative Sciences, Uludag University, Görükle Campus, \\ Nilüfer, 16059 Bursa, Turkey \\ Correspondence should be addressed to Nilüfer Taş; nilufertas@uludag.edu.tr
}

Received 23 September 2014; Revised 19 November 2014; Accepted 26 November 2014; Published 31 December 2014

Academic Editor: Gustav Visser

Copyright (c) 2014 Murat Taş et al. This is an open access article distributed under the Creative Commons Attribution License, which permits unrestricted use, distribution, and reproduction in any medium, provided the original work is properly cited.

\begin{abstract}
Bursa is one of the cities with high disaster risk and a quality housing problem in Turkey. Urban transformation activities are carried out in order to improve quality of life and create safe living spaces for sustainable urban development. Quality housing production does not signify merely a need to be satisfied quantitatively. Housing and its environment, where physical and social needs of the users are satisfied, should be designed considering local conditions and in a way that they will be suitable for users' life styles and cultural habits. In this study, the selected study area comprises neighborhoods which are under disaster risk, have been determined as urban transformation areas, and have residents with similar socioeconomic characteristics. With the purpose of improving user satisfaction, this study investigates users' experience with physical, social, and cultural features of housing and its environment, which identify the quality of housing, and their preferences of new housing units to be produced. Nonprobability sampling method was selected for the field study, and a survey study was conducted. SPSS 17.0 (Statistical Package for Social Sciences) was employed for data entry. In order to generate data for quality housing production, relationships between variables were analyzed with Pearson chi-square test.
\end{abstract}

\section{Introduction}

In recent years, significant changes in the international approaches and policies on urban risk were performed, and the need for disaster risk reduction for sustainable development was highlighted. With the United Nations Conference on Environment and Development held in Rio de Janeiro in 1992, sustainable development became a basic policy, the significance of which was recognized worldwide. The most significant contribution of Rio Conference to the concept of sustainable development is the emphasis on the need for the participation and initiative of local government units, nongovernmental organizations, private sector organizations, and individuals beside central government units in the decisions and implementations on political, economical, and social planes for the implementation of the concept of sustainable development [1].
Participation is a voluntary act that occurs when people become conscious of the value of participatory action and deem it desirable to become involved in the different activities undertaken in a participatory project or initiative [2]. The bottom-up planning process involves extensive opportunities for community participation and some unique elements, including community surveys, focus groups convened at the neighborhood level, active involvement of the city's youth, public hearings, and public awareness campaigns [3]. Participation in the formation of urban space takes place on varying levels and forms depending on the characteristics of the participant parties, the nature of the participation issue, and local characteristics. There are some excellent examples of success in this area: Rotach Street and the "Industriequartier" housing area in Zurich (Sweden) [4], Cureghem, Brussels (Belgium) [5] and Freiburg, Breisgau (Germany) [6], MakaluBarun National Park and Conservation Area Project (Nepal) 
[7], and Temple Bar, Dublin [8]. In Turkey, applications within the scope of "Dikmen Valley Urban Transformation Project" and "Portakal Çiçeği Valley Urban Transformation Project" in Ankara were the first to adopt the participation of local beneficiaries in the decision-making process [9].

In almost every city in Turkey, there are economically, socially, and environmentally deteriorated living spaces which lack quality and which did not come about in accordance with planned or orderly urbanization. The relation between disaster and city must be requestioned, quality of urban life must be improved, and urban transformation activities must be carried out to create safe living spaces in these areas. To create sustainable urban spaces in urban transformation applications, it is important that residents take part in the decision-making process and put forward their demands and expectations, legal and institutional processes be managed properly, and housing units be designed and built according to user needs, lifestyles, and local conditions.

After the 1999 Marmara Earthquake, efforts to create safer urban living spaces intensified in Turkey. To this end, urban transformation work, which commenced in previous years, began to gain its place on the agenda in 2000s. One of the most significant steps towards legitimatizing urban transformation was "Municipal Law" number 5393 of 2005. Article 69 of the law titled "land and housing production" and Article 73 titled "urban transformation and development" cover regulations on urban renewal [10]. Urban Transformation Act number 6306, enacted on May 16, 2012, covers the transformation of areas defined as areas under risk. With this law, the target is to construct approximately 14 million housing units within the scope of urban transformation in the next 20 years in Turkey. As urban transformation work became a current issue, it led to discussion on the concepts of livability-quality of life and sustainable urban development. In this context, qualities of housing that takes account of user preferences became a prominent issue. It is seen that central government plays a major role in such works as urban renewal and improvement under various regulations introduced after 2000s. Housing Development Administration of Turkey (TOKI), which is affiliated with the central government, is responsible for housing production for low incomers and renewal of the housing stock in areas under disaster risk. An examination of housing units produced by TOKI so far reveals that a large number of applications have been performed which are uniform in almost every city, have similar physical features, and adopt top-down planning process. Local qualities, unique structure, and cultural features should be taken into consideration, and local conditions of the areas to be transformed should be closely examined. Disregarding such features may lead to problems in the transformation of existing areas (e.g., Doğanbey, Bursa) and in new housing zones (e.g., permanent housing applications).

Reinforcement of sustainable lifestyles and social relationships depends largely on the design of the physical environment [11]. The most significant building type that constitutes physical built environment is housing and its environment. At the Second United Nations Conference on Human Settlements, "housing" was defined as not only a shelter but a livable unit [12]. Housing is a "social" unit where the household made up of individuals will exist together, a "physical" unit allowing for realization of various functions necessary for integrity of life, a "social" unit constituting an important pillar of individuals' and families' contact with other subjects that make up the society and where social relationships are reproduced, an "administrative" unit which is a significant part of constituting and practising urbanization policies, a "political" unit as it is the result and an indicator of class dividedness, an "economic" unit as it is a means of production and consumption and an investment tool, a "juridical" unit as legal regulations are in question and it provides the residents with legal safety, and a "technological" unit as it is the field of application for construction technologies [13]. Within the transformation of settlement system, housing, featuring all these characteristics, is not only a need to be met quantitatively, but also a body of spaces that responds to users' needs, provides a living environment where users can maintain their activities with ease, and has an environment with suitable qualities.

Bursa is one of the cities with high disaster risk and shortage of quality housing in Turkey. The main purpose of this study is to produce information that will be employed to improve quality of life and housing quality in the context of urban development in Bursa. Through getting users' opinions on how housing and its environment are used in disaster risk areas where urban transformation will be implemented, this study has investigated the following:

(i) how housing and its environment can be changed in a way to become a desirable place to live and to improve quality of life,

(ii) how physical, social, and cultural needs can be considered as a whole so as to ensure "conformity" between housing and its environment and user needs.

\section{Research Methodology}

The study was built on conceptual explanations and fieldwork. The stages of the research were selecting the areas in which to conduct the survey, preparing the survey questions, and conducting and evaluating the survey. Within the conceptual research, factors affecting the housing quality were examined by means of literature review. In field research, a total of four neighborhoods were chosen in two central districts of Bursa: two neighborhoods (Alacahırka and Pınarbaşı) in Osmangazi and two (Hocataşkın and Meydanclk) in Yildırım. These are neighborhoods that were determined as disaster risk areas and urban transformation areas by the local and central administration. There are housing units built by individuals and private sector, and the residents have similar socioeconomic characteristics. The convenience sampling method, a nonprobability sampling method, was employed for selecting the respondents for the survey, and sample size is $5 \%$ based on the population size in the study areas. To carry out field research, the survey was conducted in 740 housing units. The survey questions were aimed at physical and sociocultural evaluation of housing and its environment and determining users' value judgments and level of satisfaction. The questionnaire comprises three 
parts: the first part contains descriptive information about the household; the second part poses questions regarding the housing that the respondents presently reside in and its environment; and the questions in the third part inquire information about the respondents' housing preferences. SPSS 17.0 (Statistical Package for Social Sciences) was employed for data entry. In order to generate data for quality housing production, relationships between variables were analyzed with Pearson chi-square test.

\section{Quality of Life and Housing Quality}

Improving the physical, spatial, and social quality and quality of life in the built environment from single building scale to a citywide scale underlies sustainable development. Urban transformation practices are implemented in the world and in Turkey in line with these objectives. To ensure sustainable development, it is vital to determine the needs and expectations in different areas of the urban space and different segments of society and which tools to be employed in meeting these needs. Quality of life research is used as a tool for implementing sustainable practices that rely on policies based on scientific data in the fields of urban transformation and planning and design of housing areas [14, 15].

Quality of life, which involves the concepts of life and quality, is focused on "human" [16]. The focus of research into this area is "human-environment" relationship. The indicators that are used to determine the quality of life cover basic needs and desires of human beings and vary according to location and culture [17].

Housing, which is defined as the living space of an individual, is one of the most significant factors contributing to individual's quality of life [15, 18-21]. Housing quality accounts for both quantitative and qualitative dimensions of housing units, their immediate environment, and the needs of the occupants. There might be housing areas that are the same in terms of quantity, while they differ in terms of quality depending on local conditions and lifestyles. Quantitative dimension of housing includes objective attributes, while qualitative dimension is more subjective; thus it is difficult to measure [22].

Assessment of physical features, facilities, services, and environment makes up objective measurement of housing, while subjective measurement deals with psychosocial aspects of an individual such as perception, satisfaction, needs, and disappointment [23]. Numerous factors such as labor and materials take part in forming the objective attributes. Subjective attributes include milieus that are shaped in line with individual's self-perception such as society's value system and culture [24, 25]. While objective attributes that make up physical conditions affect each stage of housing production process (planning, design, construction, and usage), subjective attributes that form individuals' perspectives on and perceptions of physical conditions not only affect production process but also are affected by each stage. Putting forth the problems that arise depending on various factors within the whole process will ensure that quality housing will be obtained.
3.1. Production of Quality Housing. Within the context of humans' interaction with their housing and environment, examining the housing and determining user evaluations and preferences will enable making designs shaped according to local sensitivities and determining spatial needs and qualities of housing that are suited to life values. It will also contribute to developing alternative solutions which are proper in terms of quality and quantity within user-housing and user-environment relationships and which ensure sustainable development and quality of life in a new housing production process. It is necessary to assess housing quality to determine whether it is suitable for the users' family and cultural norms [23].

Various studies are available in literature in which housing and its immediate environment are evaluated by users and their preferences are determined [20, 22, 26-31]. Objective and subjective attributes are evaluated separately or, generally, together in determining housing quality. In these studies, housing is considered not only with respect to improving the quality of space but also within the context of the facilities provided by housing and residential environment. While determining housing quality, housing and its environment are investigated in terms of physical, spatial, and sociocultural dimensions that support daily life and improve quality of life. These comprise relationship among those residing in the settlement; neighborhood; shopping, entertainment, and cultural facilities provided by the settlement; social infrastructure and open areas; access to education, health, and welfare services; transportation; adequacy and quality of public transportation; environmental qualities; and safety.

In the study, while examining qualitative values of the housing units, the above-mentioned indicators were grouped, and determination of objective attributes of housing was based on two basic parameters. These parameters are "physical features" of housing and its environment and "social interaction features" which support the former. Both parameters were defined under subtitles within themselves, which are presented in Table 1 . These parameters were made into questions to get users' opinions, which were later evaluated.

\section{Findings and Evaluation}

4.1. General Description of the Study Area. Bursa is one of the cities which experienced rapid industrialization and urbanization process. With the initialization of planned development period in Turkey, significant developments on the way towards industrialization that took place in Bursa caused a large number of people to migrate from rural to urban areas. Individuals with low income provided themselves with shelters on parcels with shared ownership land registry or on unhealthy slum areas. Houses were built adjacent to each other with almost no gap between them, and they were generally multistory buildings. Settlements were not designed according to a plan. Today, there are numerous illegal settlements on Bursa Plain, on the Southern part of the city, and on the outskirts of Mount Uludağ. The settlements chosen for this study are all located on the slopes of Mount Uludağ and in Bursa Plain. They are settlement areas which 
TABLE 1: Objective attributes determining housing quality.

\begin{tabular}{|c|c|c|}
\hline \multicolumn{3}{|c|}{ Objective attributes of residential environment } \\
\hline \multicolumn{2}{|c|}{ Physical features/attributes/characteristics } & \multirow{2}{*}{$\begin{array}{l}\text { Social interaction features } \\
\text { Sociocultural facilities provided by the } \\
\text { settlement, quality of social environment }\end{array}$} \\
\hline Spatial features of housing & $\begin{array}{l}\text { Features of the immediate residential } \\
\text { environment }\end{array}$ & \\
\hline $\begin{array}{l}\text { General description of housing (type of } \\
\text { housing, exposure, and number of rooms) }\end{array}$ & $\begin{array}{l}\text { Adequacy of immediate residential } \\
\text { environment (physical environmental } \\
\text { conditions (noise, stench, polluted air, } \\
\text { privacy, security-theft, ugly image, and high } \\
\text { tension-base station), proximity to certain } \\
\text { places, main reason for residing in that } \\
\text { neighborhood, adequacy of recreational } \\
\text { facilities in the immediate residential } \\
\text { environment) }\end{array}$ & $\begin{array}{l}\text { Social infrastructure and open space (open } \\
\text { space use, recreational facilities for youth } \\
\text { and children) }\end{array}$ \\
\hline $\begin{array}{l}\text { Interior spatial features of housing (average } \\
\text { size, cupboards/cabinets, and storage) }\end{array}$ & $\begin{array}{l}\text { Municipal services (urban infrastructure: } \\
\text { sewer system, clear water, power line, } \\
\text { natural gas, roads, environmental health: } \\
\text { garbage removal, cleanliness) }\end{array}$ & Recreational facilities \\
\hline $\begin{array}{l}\text { Use of indoor spaces and spatial } \\
\text { performance (what the spaces are used for, } \\
\text { size, daylight-lightening, ventilation, } \\
\text { heating, and sound insulation performance) }\end{array}$ & Disaster resistance & Neighbor relations \\
\hline $\begin{array}{l}\text { Comfort features of housing (thermal } \\
\text { insulation, leakage-dampness-smirch, } \\
\text { privacy, light, noise, structural safety, } \\
\text { safety-security, installations, natural air } \\
\text { circulation, fire escape, and shelter) }\end{array}$ & Transportation & $\begin{array}{l}\text { Lifestyle habits such as customs and } \\
\text { traditions in the housing and environment }\end{array}$ \\
\hline $\begin{array}{l}\text { Aesthetics (how the housing is perceived, } \\
\text { aesthetics of the housing) }\end{array}$ & & \\
\hline
\end{tabular}

had been formed with similar developments over time. They feature disorderly constructed multistory buildings.

Alacahırka, Pınarbaşı, Hocataşkın, and Meydancık neighborhoods are located in the old settlement areas in Bursa. Alacahırka and Pınarbaşı neighborhoods are close to Hisariçi settlement area and the city center, also known as Hanlar Bölgesi (Caravansaries Area). Hocataşkın and Meydancık neighborhoods are near a historical area known as Yeşil and Emir Sultan, and there are many examples of civil architecture and public buildings of monumental value within their vicinity. These settlements are all located on the slopes of Mount Uludağ, and they feature disorderly constructed multistory buildings. The settlements are areas where families of lower-middle and middle income group reside. According to data from address based census in 2013 by Turkish Statistical Institute, the populations of Alacahırka, Pınarbaşı, Hocataşkın, and Meydancık are 4553, 2724, 1747, and 2659, respectively.

4.2. Survey Study. In this study, neighborhoods which are under disaster risk and have been determined as urban transformation areas were selected as the universe. Nonprobability convenience sampling method was chosen for field study due to time and cost constraints. The survey study was conducted in a total of four neighborhoods in two central districts of Bursa: two neighborhoods (Alacahırka and Pınarbaşı) in Osmangazi and two (Hocataşkın and Meydancık) in Yildirım. These neighborhoods were selected based on the fact that they are located in the city center of Bursa and they are old settlement areas. Random samples of 5\% were drawn according to the population of each neighborhood in the study areas. 740 questionnaires were carried out: 254 in Alacahırka, 176 in Pınarbaşı, 129 in Hocataşkın, and 181 in Meydancik. The data obtained in order to determine user preferences in quality housing production were analyzed with Pearson chi-square test.

4.2.1. Sociodemographic and Socioeconomic Data. As information about users is significant for housing design, residents of the settlements that were examined within the research were described. The sociodemographic and socioeconomic characteristics of the survey participants are as follows: $48.2 \%$ are female, $51.8 \%$ are male, and $63.3 \%$ are married. Regarding the household size, $36.2 \%$ have a household of 4 persons and $16.2 \%$ have a household of 5 persons. As for the number of children in the family, $31.5 \%$ have three children and $29.7 \%$ have two children. Almost all of the respondents are employed. In $50.2 \%$ of the families, only one person in the family has a job, and in $37.8 \%$ two persons work. The unemployed make up 4.3\%. Almost all of the respondents are literate. The proportion of illiterate ones is only $1.2 \%$. $66.8 \%$ of the respondents are owner-occupiers. Level of income is 
TABle 2: Average housing size and household size crosstab.

\begin{tabular}{|c|c|c|c|c|c|c|c|}
\hline \multirow{2}{*}{\multicolumn{2}{|c|}{$\begin{array}{c}\text { Average } \\
\text { housing size }\end{array}$}} & \multicolumn{5}{|c|}{ Household size } & \multirow{2}{*}{6} \\
\hline & & 1 & 2 & 3 & 4 & 5 & \\
\hline \multirow{2}{*}{ Less than $50 \mathrm{~m}^{2}$} & Count & 3 & 1 & 3 & 1 & 3 & 11 \\
\hline & $\%$ & $27.3 \%$ & $9.1 \%$ & $27.3 \%$ & $9.1 \%$ & $27.3 \%$ & $100.0 \%$ \\
\hline \multirow{2}{*}{$50-90 \mathrm{~m}^{2}$} & Count & 8 & 23 & 27 & 53 & 29 & 140 \\
\hline & $\%$ & $5.7 \%$ & $16.4 \%$ & $19.3 \%$ & $37.9 \%$ & $20.7 \%$ & $100.0 \%$ \\
\hline \multirow{2}{*}{$90-120 \mathrm{~m}^{2}$} & Count & 12 & 31 & 97 & 123 & 69 & 332 \\
\hline & $\%$ & $3.6 \%$ & $9.3 \%$ & $29.2 \%$ & $37.0 \%$ & $20.8 \%$ & $100.0 \%$ \\
\hline \multirow{2}{*}{$120-150 \mathrm{~m}^{2}$} & Count & 3 & 11 & 36 & 57 & 45 & 152 \\
\hline & $\%$ & $2.0 \%$ & $7.2 \%$ & $23.7 \%$ & $37.5 \%$ & $29.6 \%$ & $100.0 \%$ \\
\hline \multirow{2}{*}{$150-180 \mathrm{~m}^{2}$} & Count & 1 & 3 & 14 & 17 & 19 & 54 \\
\hline & $\%$ & $1.9 \%$ & $5.6 \%$ & $25.9 \%$ & $31.5 \%$ & $35.2 \%$ & $100.0 \%$ \\
\hline \multirow{2}{*}{ Total } & Count & 27 & 69 & 177 & 251 & 165 & 689 \\
\hline & $\%$ & $3.9 \%$ & $10.0 \%$ & $25.7 \%$ & $36.4 \%$ & $23.9 \%$ & $100.0 \%$ \\
\hline
\end{tabular}

significant to the quality of the housing. The mean income level per month is $€ 1,000$ and above. $28.7 \%$ of the respondents have a monthly income of $€ 2,000$ and above.

4.2.2. Information about the Housing. For sustainable urban development and quality of life it is vital to create a physical environment in which physical and psychosocial needs of humans are satisfied on the scale of both settlement and housing unit. Meeting spatial needs of humans in the housing unit and its environment and arrangements that enable social interaction are significant for increasing housing satisfaction. To this end, needs and expectations of the society and individuals were researched. In the study, housing units were examined to determine qualitative values of the housing units.

\section{(1) Physical Features}

(a) Spatial Features of the Housing. Shape of the housing and features of the spaces in the housing are among the most significant factors affecting housing satisfaction. Design criteria such as the type, location, size, and exposure of the housing and the number of rooms determine the shape of the housing. Design criteria such as the size, usage, flexibility of spaces in the housing, and their responding to users' needs determine features regarding spatial organization.

Within the scope of this study, general information about the housing was obtained, and an evaluation of the housing based on a scale of 1 to 5 was made to determine the level of satisfaction. Regarding the general features of the current housing unit, the survey results show that a large proportion of the participants live in apartments in single apartment buildings (44.7\%), with two facades (50.2\%), 90-120 $\mathrm{m}^{2}$ with a living room and three bedrooms (54.7\%), facing east $(30.6 \%)$, and being heated with a floor standing boiler (39.8\%) (Figure 1).

According to survey data, residents are satisfied with the type of housing (51.4\%), housing size (46.8\%), number of rooms (54.7\%), exposure (47.6\%), number of facades (50.2\%), heating system (42.4\%), and housing design (53.5\%).

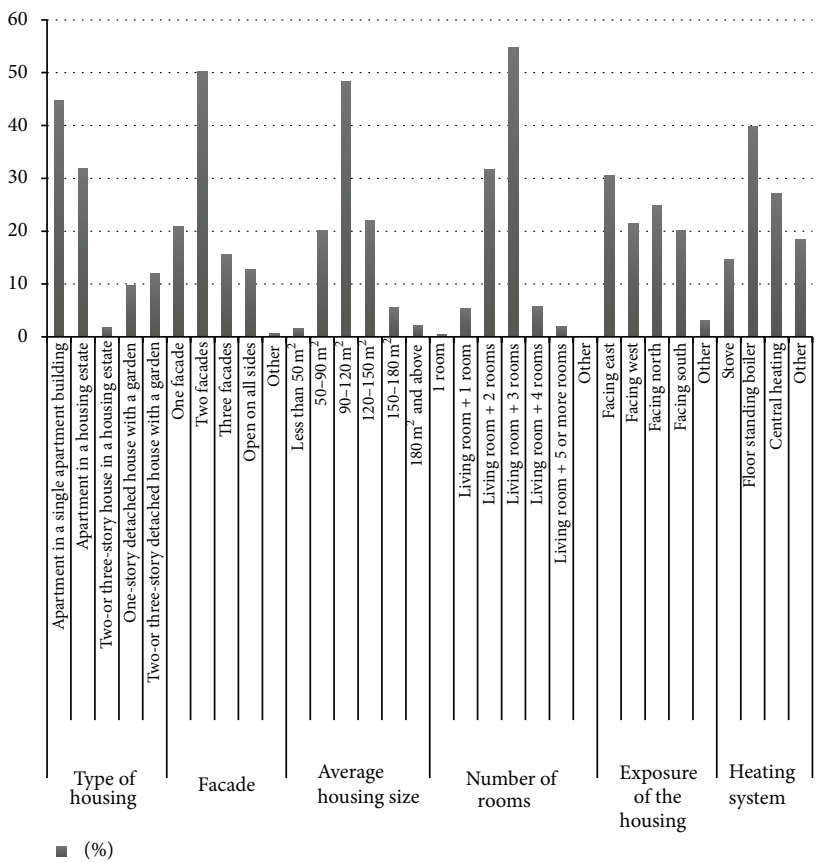

FIgURE 1: Overall description of housing.

According to the Pearson chi-square statistics, there is a significant relationship between household income and housing type $\left(x^{2}(12)=63.603, P<0.05\right)$, housing type and household size $\left(x^{2}(15)=26.391, P<0,05\right)$, and housing size and household income $\left(x^{2}(12)=112.524, P<0,05\right)$. Statistics shows that as the level of income rises families prefer to live in larger housing units.

It was determined that there is relationship between number of rooms and household income $\left(x^{2}(12)=62.992\right.$, $P<0,05)$. Statistics shows that as the level of income rises families prefer to live in housing units with more rooms.

According to average housing size and household size crosstab (Table 2), households with one, three, or five persons living in $50 \mathrm{~m}^{2}$ or smaller housing units make up $27.3 \%$, 


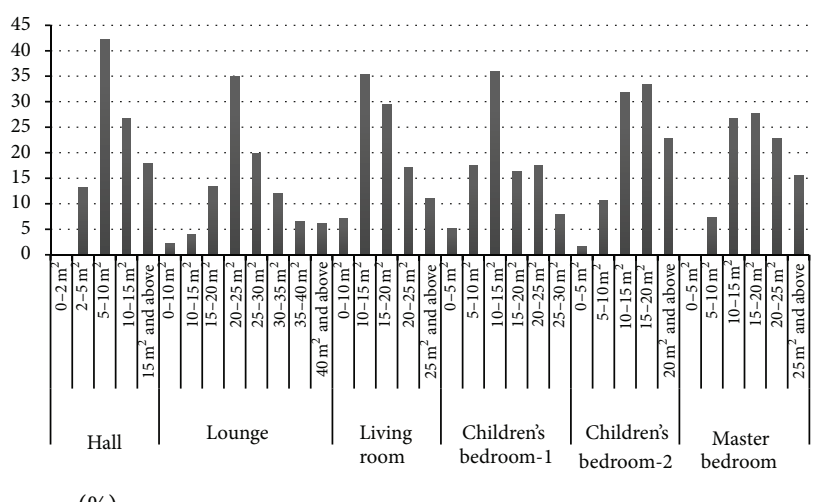

- $(\%)$

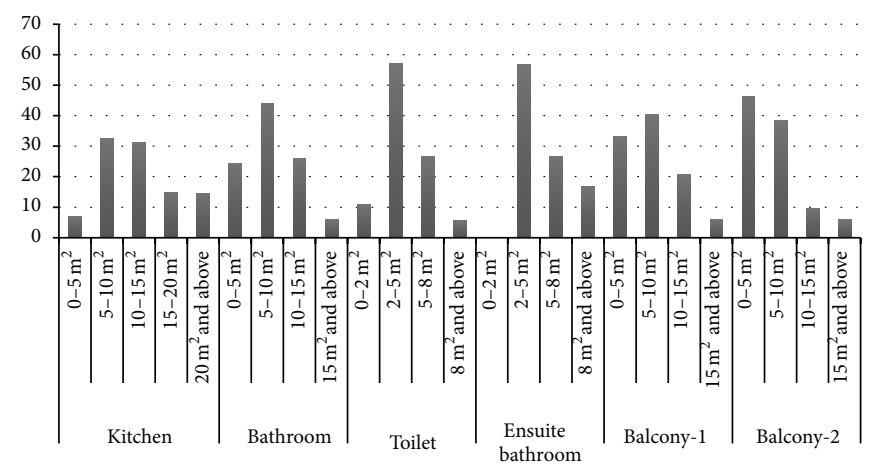

- $(\%)$

(a)

(b)

FIGURE 2: (a) Size of interior spaces. (b) Size of interior spaces.

households with four persons living in $50-90 \mathrm{~m}^{2}$ housing units make up $37.9 \%$, households with four persons living in $90-120 \mathrm{~m}^{2}$ housing units make up $37 \%$, households with four persons living in $120-150 \mathrm{~m}^{2}$ housing units make up $37.5 \%$, and households with four persons living in $150-180 \mathrm{~m}^{2}$ housing units make up $35.2 \%$. According to average housing size and household size crosstab (Table 2), as the household size increases, families live in larger housing units. It was determined that there is the relationship between average housing size and household size $\left(x^{2}(16)=40.555, P<0,05\right)$.

Interior Spatial Features of Housing. Size of interior spaces and storage area are among factors that affect housing satisfaction. The purpose of determining the size of interior spaces is to determine the adequateness of the space in meeting the household's needs. Research has stated that the sizes of interior spaces of housing units and their use vary according to socioeconomic structure. It has been observed that the better the socioeconomic structure, the larger the space size that users prefer [32]. Users stated that they were generally satisfied with the size of interior spaces (Figures 2(a), 2(b), and 3) and cabinets (44.2\%) and storage (34.7\%). The cabinets and storage areas in housing units are especially used for storing foodstuff prepared for summer and winter. In addition, although the families residing in the study area are nuclear families, they have strong family relationships and they have houseguests, so they use these areas for storing mattresses, quilts, and so on. Functionality of the housing unit is significant in meeting the needs of the family which, at times, becomes larger.

Usage of the Spaces in the Housing Unit. Being able to perform actions in accordance with the needs in the housing and the housing units meeting the conditions for performing these actions affect housing satisfaction. Users were asked about their opinions about the usage of spaces. According to survey data, spaces are separated based on their functions.

According to the survey data, the lounge is used for entertaining guests (64.9\%) and sitting (14.4\%); the living room is used for watching television (43.4\%) and sitting

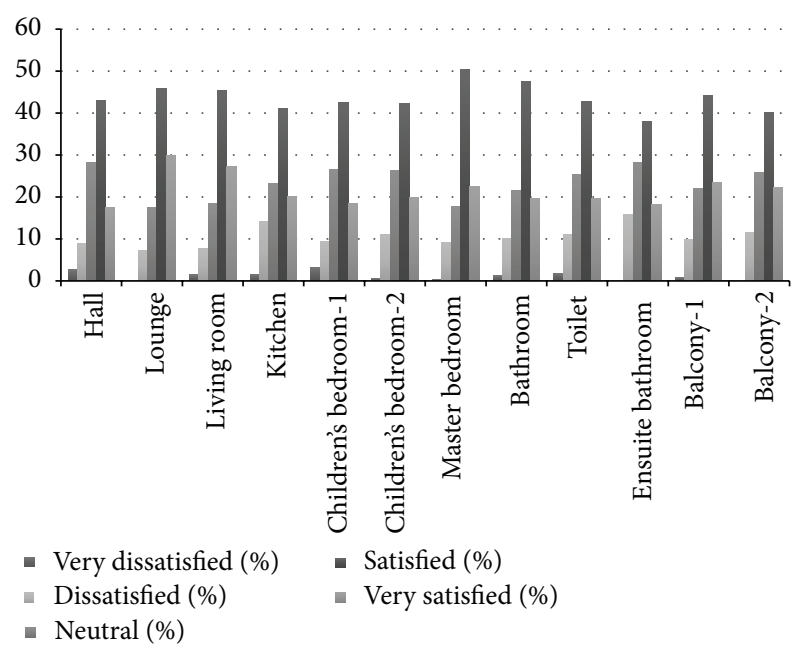

FIgURE 3: Satisfaction with the size of interior spaces.

(42.8\%); the bedrooms are used for sleeping (children's bedroom $55.8 \%$, master bedroom $95.3 \%)$; the kitchen is used for cooking (62.6\%) and eating (34.2); the bathroom is used for bathing (93.5\%); the terrace (48.4\%) and the garden $(50.4 \%)$ are used for sitting in summer; and the attic is used for storing (33.3\%) and sitting (20\%) in summer.

Comfort Features of the Housing. Comfort features of the housing make up one of the significant factors affecting user satisfaction. Users were asked to evaluate comfort features of the housing and to see if there are any complaints about comfort features. Participants stated that they are satisfied with the comfort features (Figure 4(a)) and that they do not have any complaints about comfort features (Figure 4(b)).

According to Pearson chi-square statistic, thermal insulation of the housing unit $\left(x^{2}(6)=41.275, P<0,05\right)$; waterproofing of the housing unit $\left(x^{2}(12)=63.603, P<0,05\right)$; natural air circulation in the housing unit $\left(x^{2}(9)=24.836\right.$, $P<0,05)$; the amount of natural light in the housing unit $\left(x^{2}(9)=31.879, P<0,05\right)$; structural safety of the housing 


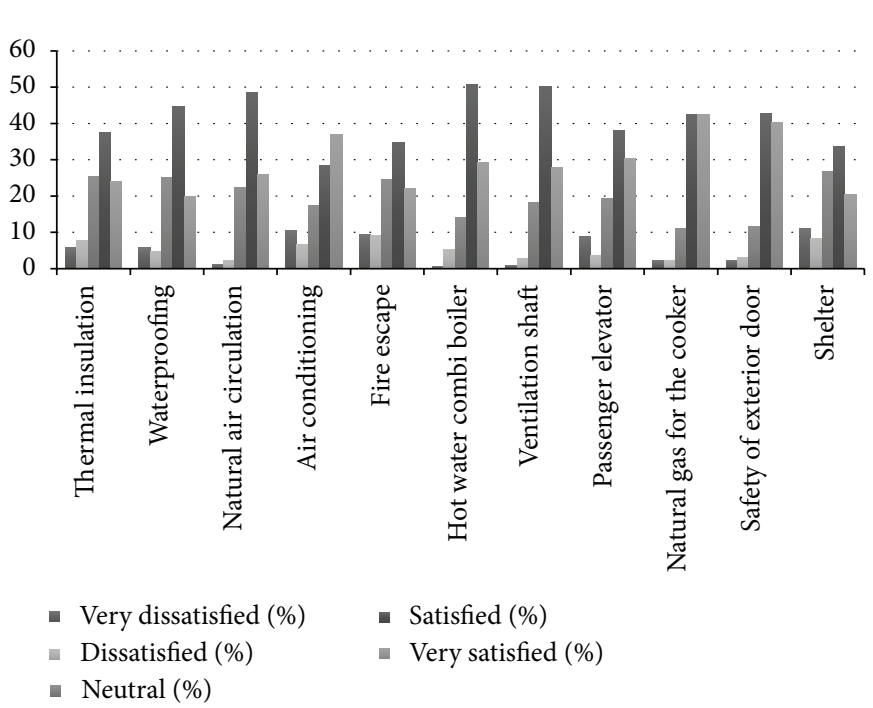

(a)

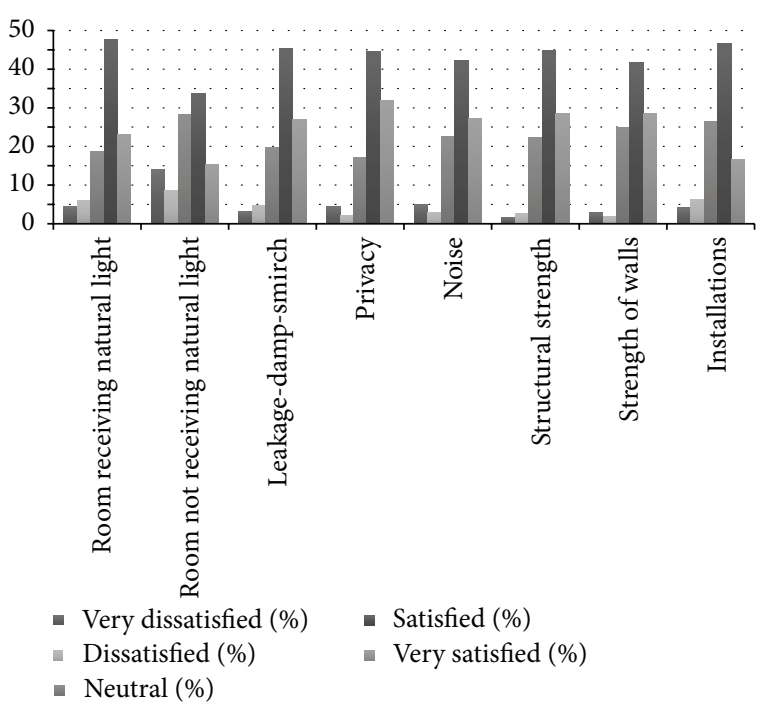

(b)

FIGURE 4: (a) Evaluation of comfort features of housing. (b) Evaluation of comfort features of housing.

TABLE 3: Architectural aesthetics of the housing and housing satisfaction crosstab.

\begin{tabular}{|c|c|c|c|c|c|c|c|}
\hline \multirow{2}{*}{\multicolumn{2}{|c|}{$\begin{array}{c}\text { Architectural } \\
\text { aesthetics }\end{array}$}} & \multicolumn{5}{|c|}{ Satisfaction with architectural aesthetics } & \multirow{3}{*}{$\begin{array}{c}\text { Total } \\
88\end{array}$} \\
\hline & & \multirow{2}{*}{$\frac{\text { Very dissatisfied }}{3}$} & \multirow{2}{*}{$\frac{\text { Dissatisfied }}{3}$} & \multirow{2}{*}{$\frac{\text { Neutral }}{9}$} & \multirow{2}{*}{$\frac{\text { Satisfied }}{26}$} & \multirow{2}{*}{$\frac{\text { Very satisfied }}{47}$} & \\
\hline Modern & Count & & & & & & \\
\hline & $\%$ & $3.4 \%$ & $3.4 \%$ & $10.2 \%$ & $29.5 \%$ & $53.4 \%$ & $100.0 \%$ \\
\hline \multirow{2}{*}{ Traditional } & Count & 4 & 1 & 7 & 36 & 19 & 67 \\
\hline & $\%$ & $6.0 \%$ & $1.5 \%$ & $10.4 \%$ & $53.7 \%$ & $28.4 \%$ & $100.0 \%$ \\
\hline \multirow{2}{*}{ Ordinary } & Count & 13 & 28 & 150 & 188 & 52 & 431 \\
\hline & $\%$ & $3.0 \%$ & $6.5 \%$ & $34.8 \%$ & $43.6 \%$ & $12.1 \%$ & $100.0 \%$ \\
\hline \multirow{2}{*}{ No aesthetics } & Count & 18 & 21 & 38 & 20 & 16 & 113 \\
\hline & $\%$ & $15.9 \%$ & $18.6 \%$ & $33.6 \%$ & $17.7 \%$ & $14.2 \%$ & $100.0 \%$ \\
\hline \multirow{2}{*}{ Total } & Count & 38 & 53 & 204 & 270 & 134 & 699 \\
\hline & $\%$ & $5.4 \%$ & $7.6 \%$ & $29.2 \%$ & $38.6 \%$ & $19.2 \%$ & $100.0 \%$ \\
\hline
\end{tabular}

and housing satisfaction $\left(x^{2}(9)=86.924, P<0,05\right)$; privacy in the housing and housing satisfaction $\left(x^{2}(9)=40.525\right.$, $P<0,05)$; and leakage-dampness-smirch in the housing unit $\left(x^{2}(9)=24.836, P<0,05\right)$ increase housing satisfaction. As a result, it is seen that comfort features of the housing affect housing satisfaction.

Aesthetics. An evaluation was made about building aesthetics, a significant factor in meeting such needs as respectability (status, prestige, gaining recognition, etc.), based on respondents' perceptions. Physical appearance of the housing units in the areas where the survey was conducted can be described as uniform ordinary structures without a certain architectural feature (Figures 12, 13, and 14). Respondents were asked how they found architectural aesthetics of the housing units they reside in. Of the participants, $61.5 \%$ stated that they found their housing units ordinary, and $12.6 \%$ found them modern.

Crosstab shows that $53.4 \%$ of those living in modern buildings are very satisfied; $53.7 \%$ of those living in traditional buildings are satisfied; $43.6 \%$ of those living in ordinary buildings are satisfied, while $33.4 \%$ of those living in buildings with no aesthetic features are neutrally satisfied with the housing (Table 3). There is a relationship between architectural aesthetics of the housing and housing satisfaction $\left(x^{2}(12)=167.583, P<0,05\right)$. Level of satisfaction rises in more modern housing units. There is a relationship between satisfaction with architectural aesthetics of housing and ownership status $\left(x^{2}(8)=23.426, P<0\right.$, 05). Participants' being owners of the housing units affects satisfaction with aesthetics of the housing.

Users having a monthly household income of over $€ 2001$ and residing in modern housing units make up $47.7 \%$; those having a monthly household income of $€ 1001-1500$ and residing in traditional buildings make up 26.9\%; those with a monthly household income of $€ 1001-1500$ and residing in ordinary buildings make up 28.4\%; and those having a monthly household income of over $€ 2001$ and residing in buildings with no architectural aesthetics make up 26.5\% 
TABLE 4: Architectural aesthetics of the housing and household income crosstab.

\begin{tabular}{|c|c|c|c|c|c|c|c|}
\hline \multirow{2}{*}{\multicolumn{2}{|c|}{$\begin{array}{c}\text { Architectural } \\
\text { aesthetics }\end{array}$}} & \multicolumn{5}{|c|}{ Monthly household income } & \multirow{3}{*}{$\begin{array}{c}\text { Total } \\
88\end{array}$} \\
\hline & & \multirow{2}{*}{$\begin{array}{c}\text { Minimum wage } \\
0\end{array}$} & \multirow{2}{*}{$\frac{680-1000}{8}$} & \multirow{2}{*}{$\frac{1001-1500}{8}$} & \multirow{2}{*}{$\frac{1501-2000}{30}$} & \multirow{2}{*}{$\frac{2001 \text { and above }}{42}$} & \\
\hline Modern & Count & & & & & & \\
\hline Modern & $\%$ & $.0 \%$ & $9.1 \%$ & $9.1 \%$ & $34.1 \%$ & $47.7 \%$ & $100.0 \%$ \\
\hline \multirow{2}{*}{ Traditional } & Count & 5 & 13 & 18 & 17 & 14 & 67 \\
\hline & $\%$ & $7.5 \%$ & $19.4 \%$ & $26.9 \%$ & $25.4 \%$ & $20.9 \%$ & $100.0 \%$ \\
\hline \multirow{2}{*}{ Ordinary } & Count & 25 & 63 & 122 & 103 & 116 & 429 \\
\hline & $\%$ & $5.8 \%$ & $14.7 \%$ & $28.4 \%$ & $24.0 \%$ & $27.0 \%$ & $100.0 \%$ \\
\hline \multirow{2}{*}{ No aesthetics } & Count & 16 & 25 & 22 & 20 & 30 & 113 \\
\hline & $\%$ & $14.2 \%$ & $22.1 \%$ & $19.5 \%$ & $17.7 \%$ & $26.5 \%$ & $100.0 \%$ \\
\hline \multirow{2}{*}{ Total } & Count & 46 & 109 & 170 & 170 & 202 & 697 \\
\hline & $\%$ & $6.6 \%$ & $15.6 \%$ & $24.4 \%$ & $24.4 \%$ & $29.0 \%$ & $100.0 \%$ \\
\hline
\end{tabular}

TABLE 5: Housing satisfaction and ownership crosstab.

\begin{tabular}{|c|c|c|c|c|c|}
\hline \multirow{2}{*}{\multicolumn{2}{|c|}{$\begin{array}{c}\text { Housing } \\
\text { satisfaction }\end{array}$}} & \multicolumn{3}{|c|}{ Ownership status } & \multirow{3}{*}{$\begin{array}{c}\text { Total } \\
95\end{array}$} \\
\hline & & \multirow{2}{*}{$\frac{\text { Homeowner }}{74}$} & \multirow{2}{*}{$\begin{array}{c}\text { Tenant } \\
17\end{array}$} & \multirow{2}{*}{$\frac{\text { Public housing and free tenant }}{4}$} & \\
\hline Very satisfied & Count & & & & \\
\hline very satisiled & $\%$ & $77.9 \%$ & $17.9 \%$ & $4.2 \%$ & $100.0 \%$ \\
\hline \multirow{2}{*}{ Satisfied } & Count & 263 & 84 & 7 & 354 \\
\hline & $\%$ & $74.3 \%$ & $23.7 \%$ & $2.0 \%$ & $100.0 \%$ \\
\hline \multirow{2}{*}{ Neutral } & Count & 105 & 78 & 3 & 186 \\
\hline & $\%$ & $56.5 \%$ & $41.9 \%$ & $1.6 \%$ & $100.0 \%$ \\
\hline \multirow{2}{*}{ Dissatisfied } & Count & 20 & 25 & 2 & 47 \\
\hline & $\%$ & $42.6 \%$ & $53.2 \%$ & $4.3 \%$ & $100.0 \%$ \\
\hline \multirow{2}{*}{ Total } & Count & 462 & 204 & 16 & 682 \\
\hline & $\%$ & $67.7 \%$ & $29.9 \%$ & $2.3 \%$ & $100.0 \%$ \\
\hline
\end{tabular}

(Table 4). According to Pearson chi-square statistic, there is a relationship between architectural aesthetics of housing and household income $\left(x^{2}(12)=53.474, P<0,05\right)$. As the level of income rises, users prefer to live in more modern housing units.

\section{(b) Features about Immediate Residential Environment}

Adequacy of Immediate Housing Environment. Participants were asked about their opinions about the neighborhood, immediate environment, and housing. Of all participants, $50.6 \%$ are satisfied with the neighborhoods that they reside in, $43.6 \%$ are dissatisfied with immediate environment, and $51.9 \%$ are dissatisfied with the housing units.

While survey participants state that they are satisfied with certain design factors (type of housing, number of facades, housing size, number of rooms, exposure, heating system, and design) which affect satisfaction, at the same time they state that they are not satisfied with the housing. This suggests that users find the housing units adequate in terms of size, dimensions, and meeting their needs, and they are happy to own the housing; but on the other hand, they have expectations for better spaces as a social need.

Those who are very satisfied with the housing and are homeowners make up $77.9 \%$; those who are satisfied with the housing and are homeowners make up 74.3\%; those who are neutrally satisfied with the housing and are homeowners make up 56.5\%; and those who are not satisfied with the housing and are tenants make up 53.2\% (Table 5). There is a relationship between satisfaction with housing and ownership status $\left(x^{2}(6)=40.976, P<0.05\right)$. Being the owner of the housing unit increases housing satisfaction.

Regarding adequacy of immediate housing environment, participants were asked dichotomous questions that ask for a yes/no response. Within this scope, it was determined that on the whole there are no problems about noise, stench, polluted air, privacy, security-theft, ugly image, and high tension-base station, all of which were mentioned under the heading of physical environmental conditions (Figure 5). According to the majority of participants $(70 \%-89 \%)$, there are problems about proximity.

Within the context of the main reason for residing in the neighborhood (Figure 5), participants were asked to rate the adequacy of neighbor relations, fellow-townsmenship relations, kinship relations, social solidarity, inexpensiveness, and quality of life. Participants stated that neighbor relations, fellow-townsmenship relations, and quality of life are adequate; however, the residential environment is not adequate in terms of kinship relations, social solidarity, and inexpensiveness (Figure 5). 


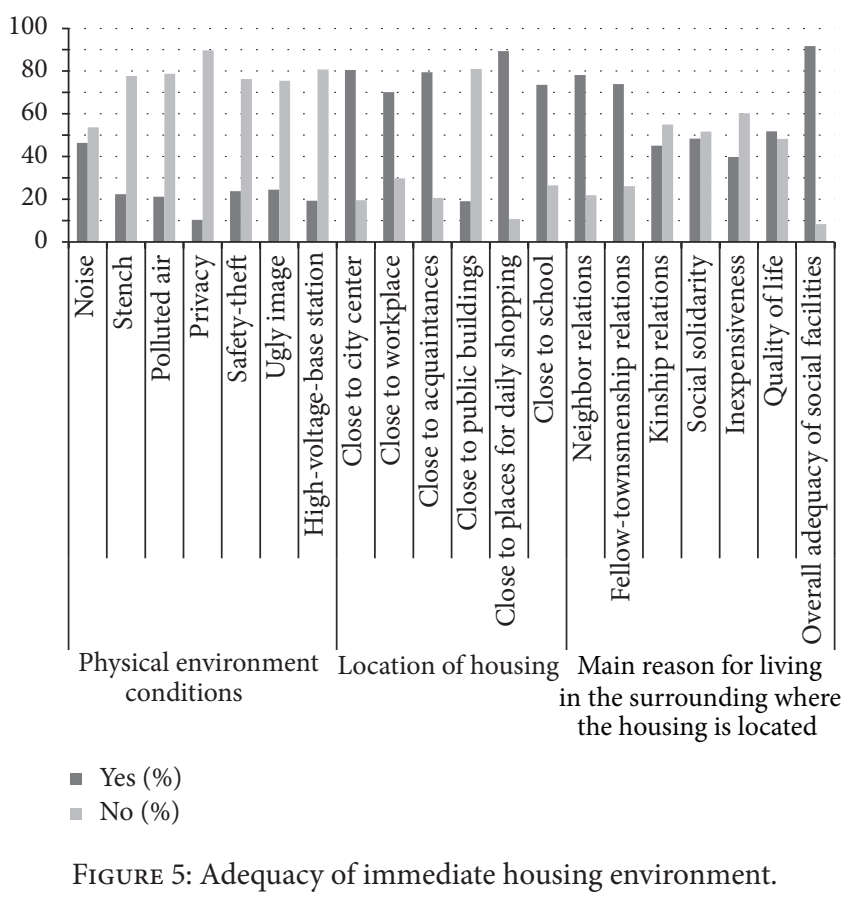

According to Pearson chi-square statistics, lack of noise $\left(x^{2}(12)=105.439, P<0,05\right)$, stench $\left(x^{2}(9)=107.811, P<\right.$ $0,05)$, high-voltage line $\left(x^{2}(9)=73.704, P<0,05\right)$, and an ugly image $\left(x^{2}(12)=72.324, P<0,05\right)$; ensuring privacy $\left(x^{2}(9)=80.982, P<0,05\right)$; sufficient roads and parking areas $\left(x^{2}(12)=49.990, P<0,05\right)$; and security-theft $\left(x^{2}(12)=\right.$ $32.854, P<0,05)$ increase housing satisfaction.

Municipal Services. Services provided by municipalities are important for improving quality of life. Participants find municipal services in their housing environment inadequate (42.7\%). It was determined that there are problems about urban infrastructure (sewerage, clean water, power lines, natural gas, etc.) (79.1) and roads (80.8\%); however, there are no problems about environmental health (garbage removal and cleanup) (71.9\%). It is thought that dissatisfaction with roads results from such problems as limited alternatives for the roads providing access to the city center, traffic density, insufficient road width, and features of urbanization. According to Pearson chi-square analysis, there is a relationship between satisfaction with municipal services and housing satisfaction $\left(x^{2}(12)=200.7, P<0.05\right)$.

Resistance of Housing and Its Environment to Disasters Such as Earthquakes, Floods, and Strong Southwester. To ensure sustainable development, human life and properties must not be under big risks, and necessary precautions must be taken to reduce existing risks. When participants were asked how they felt towards the resistance of the housing unit and its environment to disasters such as earthquakes, floods, and strong southwester, they stated that they do not feel safe in their housing units (40.5\%); however, they feel safe in the residential environment (38.6\%). It is safe to say that participants do not feel protected against natural disasters, especially earthquakes, because of problems with the housing and the settlement; for example, surveyed settlements were not constructed according to a certain plan, buildings were not constructed in accordance with earthquake regulations, and low-rise housing units in the urban fabric were not sufficient in number, so they were demolished and replaced by multistory apartment buildings (shanty houses were replaced by multistory apartments in time).

Transportation. Transportation is one of the factors that support social integration in the society [33]. Ensuring the effectiveness of transportation in everyday life is important in terms of improving quality of life and individuals' happiness. Adequate and economically affordable transportation increases mobility of public within the city and contributes to the improvement of social relationships.

In the study, $50 \%$ of the participants stated that they own a car, and $65.5 \%$ experience parking lot problems. The means of transport available in the immediate housing environment for accessing the city center or other areas are as follows, in order of preference: buses (100\%), taxis $(90.1 \%)$, pedestrian walks $(75.3 \%)$, minibuses $(69.2 \%)$, the rail system $(44 \%)$, and cycle lanes as the least preferred (33.5\%).

As for the evaluation of vehicles for access to city center and other important spots, participants are satisfied on the whole. Participants are satisfied with buses (45.7), minibuses (47.1), taxis (49.1), cycle lanes (30.2\%), and pedestrian walks (47.1\%). $41.8 \%$ of the participants stated that they are very satisfied with the rail system which is a newly developing means of transport in Bursa.

\section{(2) Social Interaction Features}

The Use of Social Infrastructure and Open Space. The availability of social infrastructure and open space that meet the needs of people of different age groups affects satisfaction with the housing and its environment. While such areas might have a negative effect on social interaction, they also enable users to move away from conditions of everyday life and relax psychologically, and they strengthen social relations.

Survey participants stated that there are gardens (57.7\%) and open spaces (61.8\%) in the housing environment and that they are mostly satisfied with the use of them. According to the survey data, open spaces are used effectively. In order of importance, open spaces are used for sitting-resting (79.4\%), playgrounds (68.3\%), parking areas (62.1\%), and gardens (61.8\%). Regarding satisfaction with the use of open spaces, participants are satisfied with the use of open spaces as a garden $(36.9 \%)$, parking lot (34.9\%), sports areas (32.7\%), atelier (45.5\%), and playground (45.5\%), for sitting-resting $(45.7 \%)$ and social activity (33\%). The research showed that children play in the street. Friendship that children make while playing in the street will help them develop social relations, contribute to neighbor relations, and improve the sense of belonging to a community.

According to chi-square statistic, there is a relationship between satisfaction with the open spaces in the housing environment and housing satisfaction $\left(x^{2}(9)=80.338, P<\right.$ $0.05)$, satisfaction with social activity areas and gender 


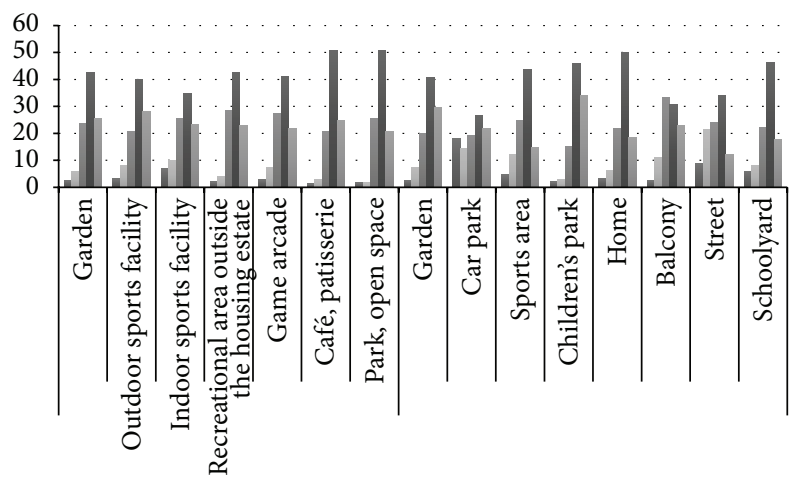

$$
\begin{array}{ll}
\begin{array}{c}
\text { Usage of social facilities } \\
\text { by teenagers }
\end{array} & \text { Places where children play } \\
\text { - Very dissatisfied (\%) } & \text { - Satisfied (\%) } \\
\text { - Dissatisfied (\%) } & \text { - Very satisfied (\%) }
\end{array}
$$$$
\text { - Neutral (\%) }
$$

FIgURE 6: Recreational facilities for youth and children.

$\left(x^{2}(4)=17.701, P<0.05\right)$. Results of the analysis show that in the design of housing environment arrangements should be made according to the needs of both male and female users.

According to chi-square statistic, there is a significant relationship between satisfaction with the garden in the immediate housing environment and age $\left(x^{2}(20)=40.769\right.$, $P<0.05)$, satisfaction with the sports areas in the immediate housing environment and age $\left(x^{2}(20)=41.267, P<0.05\right)$, and satisfaction with the sitting-resting area in the immediate housing environment and age $\left(x^{2}(16)=28.918, P<0.05\right)$. Results of the analysis show that design of the immediate housing environment should include spatial arrangements for the needs of different age groups.

It is seen that youth and children are satisfied with the facilities that the housing and its environment offer (Figure 6). Teenagers prefer to spend their free time in the open spaces, cafes, and patisseries in the immediate housing environment. Younger children play at home, in schoolyards, in children's playgrounds, and in sports areas.

Social Facilities in the Immediate Residential Environment. Availability of cultural buildings, commercial buildings, and education buildings that enable individuals to maintain their lives and ensure their sociocultural development and interaction with others in the residential settlement on the scale of neighborhood affects the satisfaction with the housing and its environment [34]. Survey participants are mostly satisfied with social facilities in the immediate housing environment (Figure 7).

According to data from the participants, among the most commonly used facilities, primary schools rank first, supermarkets rank second, and religious facilities rank third.

According to chi-square statistic, there is a significant relationship between satisfaction with the parks in the immediate housing environment and housing satisfaction $\left(x^{2}(9)=\right.$ 79.783, $P<0.05)$, satisfaction with the marketplace in

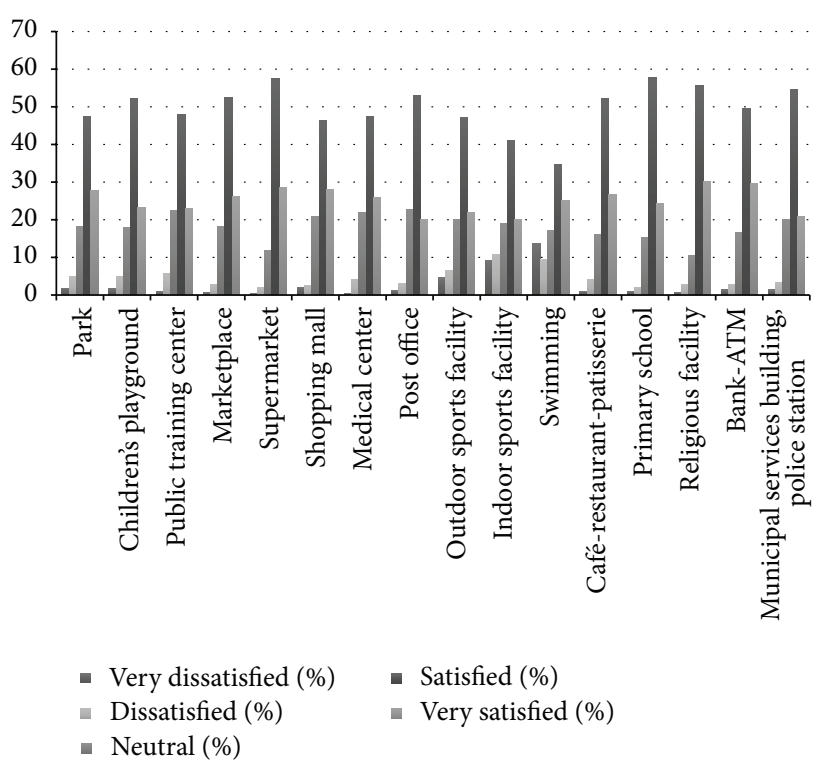

Figure 7: Adequacy of social facilities in immediate housing environment.

the immediate housing environment and housing satisfaction $\left(x^{2}(9)=85.451, P<0.05\right)$, satisfaction with having a medical center in the immediate housing environment and housing satisfaction $\left(x^{2}(9)=66.347, P<0.05\right)$, satisfaction with having a religious facility in the immediate housing environment and housing satisfaction $\left(x^{2}(9)=50.423, P<0.05\right)$, satisfaction with the outdoor sports facilities in the immediate housing environment and housing satisfaction $\left(x^{2}(9)=\right.$ 44.4740, $P<0.05$ ), satisfaction with having supermarkets/ stores for daily shopping in the immediate housing environment and housing satisfaction $\left(x^{2}(9)=57.270, P<\right.$ 0.05 ), and satisfaction with having a primary school in the immediate housing environment and housing satisfaction $\left(x^{2}(9)=63.663, P<0.05\right)$. According to the results of the analysis, social facilities in the immediate housing environment affect satisfaction with the housing and its environment.

Neighbor Relations. As implied in the proverb "do not buy the house, buy the neighborhood," the level of social relationship with neighbors affects user satisfaction, and it is one of the most significant features for determining housing quality. According to the data, $33.5 \%$ of the survey participants see their neighbors several times a week and the most common way of seeing neighbors is home visits. The issues that create conflict among neighbors are cleaning, building maintenance and repairs, and heating. The majority of participants wish to live together with their present neighbors in the future (Figure 8).

Customs, Traditions, and Life Habits Realized in the Housing and Immediate Residential Environment. According to the responses to the open ended question regarding customary habits realized in the housing and its immediate environment, activities such as washing carpets and wool, preparing food 


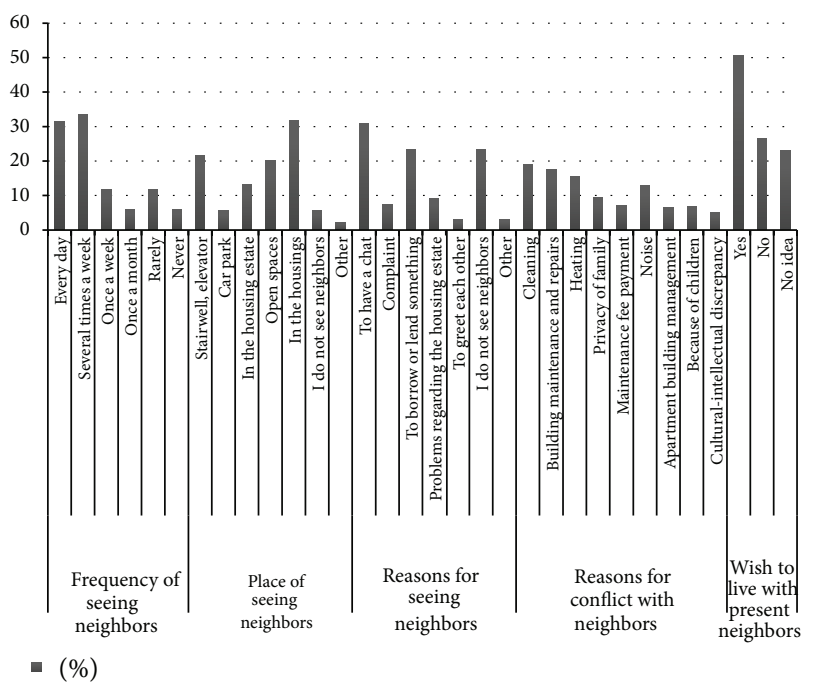

FiguRE 8: Neighbor relations.

for winter, henna night, and wedding feasts are maintained. $38.6 \%$ of the participants are satisfied, and $29.2 \%$ are very satisfied with the convenience of their housing units for traditions and customs. Customs, traditions, and life habits can be regarded as an indicator of the existence of social and cultural relationships and the need to sustain them.

\subsubsection{Information about Preferred Housing/Description of Pre-} ferred Housing. Participants' wish to move home if they have the financial means, description of the preferred housing, and preferred sociocultural facilities were investigated based on participants' views.

$43 \%$ of the participants wish to move house if they have the financial means, while $42.6 \%$ do not. The top three reasons for wanting to move are that participants need a large and comfortable home (32.3\%), dream of a better housing unit (20\%), and want a different housing type (18.2\%) (Figure 9). According to the research, quality of the preferred housing unit changes as socioeconomic structure is better [32]. This study suggests that even though the survey participants are generally satisfied with their housing units, they would like to move if they have better financial means.

If the participants had better financial means, the ideal housing unit would be in the city center (34\%), and the preferred housing type would be a detached house with a garden. Participants prefer a $120-150 \mathrm{~m}^{2}$ housing unit (38.3\%), with a lounge and three rooms (41\%), heated with a floor standing boiler (45.5\%). The preferred apartment building is a 2- or 3-story (38.3\%) apartment building with 2 housing units on each story (53.1\%).

The top three features of the location of preferred housing are as follows, in order of preference: easy access to the city center $(69.7 \%)$, proximity to the workplace $(39.6 \%)$, and health facilities (36.4\%). Shopping facilities (26.4\%) and security (21.6) rank fourth and fifth in the list, respectively.

Participants were asked for their views on the upsides and downsides of living in an apartment building and in

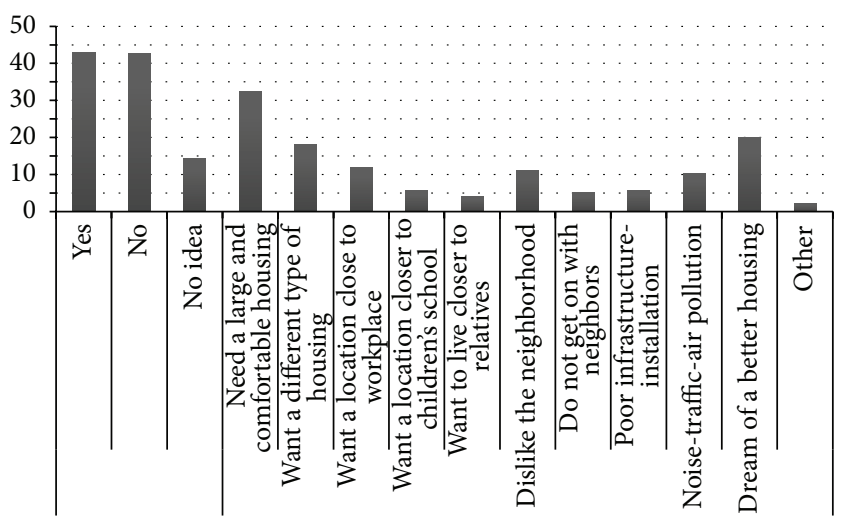

Want to move to another place

- $(\%)$

FIGURE 9: Comments on wanting to move.

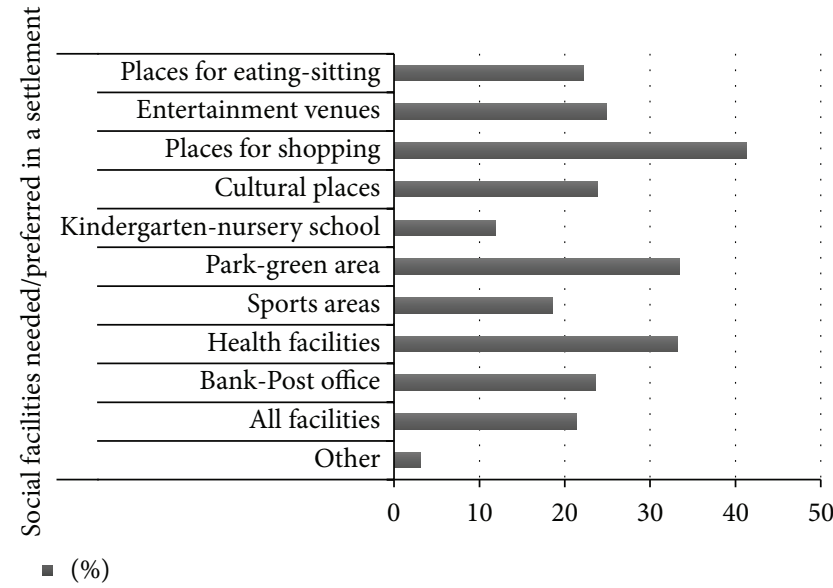

FIGURE 10: Comments on social facilities needed/preferred in a settlement.

a detached house. Respondents suggested "security (36.6\%)" and "having people around (26.3\%)" as the advantages and "noise (43.6\%)" and "difficulty in making a decision (39.1\%)" as the disadvantages of living in an apartment building. As for living in a detached house, "comfort (67.1\%)," "privacy (22.7\%)," and "quietness (67.1\%)" were suggested as advantages, while "loneliness (41.4\%)" and "costliness (24.8\%)" were suggested as disadvantages. In Turkey, the need for a balance between the need for integration and disintegration is emphasized [35]. The results of the survey study support this idea and suggest that we need living spaces where people can spend time on their own, while at the same time they can be in a relationship with their surroundings.

According to participants' views, the top three types of social facilities that are needed/preferred in a settlement are places for shopping (41.3\%), parks/green areas (33.4\%), and health facilities (33.2\%) in order of preference (Figure 10).

According to the preferred housing size and age crosstab (Table 6), the middle-aged and the elderly want to live in smaller housing units, while the young prefer larger ones. 
TABle 6: Preferred housing size and age crosstab.

\begin{tabular}{|c|c|c|c|c|c|c|c|}
\hline \multirow{2}{*}{\multicolumn{2}{|c|}{$\begin{array}{l}\text { Preferred average } \\
\text { housing size }\end{array}$}} & \multicolumn{5}{|c|}{ Age } & \multirow{2}{*}{ Total } \\
\hline & & $18-28$ & $28-38$ & $38-48$ & $48-58$ & 58 and above & \\
\hline \multirow{2}{*}{$50-90 \mathrm{~m}^{2}$} & Count & 2 & 3 & 8 & 4 & 3 & 20 \\
\hline & $\%$ & $10.0 \%$ & $15.0 \%$ & $40.0 \%$ & $20.0 \%$ & $15.0 \%$ & $100.0 \%$ \\
\hline \multirow{2}{*}{$90-120 \mathrm{~m}^{2}$} & Count & 17 & 33 & 36 & 33 & 14 & 133 \\
\hline & $\%$ & $12.8 \%$ & $24.8 \%$ & $27.1 \%$ & $24.8 \%$ & $10.5 \%$ & $100.0 \%$ \\
\hline \multirow{2}{*}{$120-150 \mathrm{~m}^{2}$} & Count & 50 & 62 & 63 & 45 & 28 & 248 \\
\hline & $\%$ & $20.2 \%$ & $25.0 \%$ & $25.4 \%$ & $18.1 \%$ & $11.3 \%$ & $100.0 \%$ \\
\hline \multirow{2}{*}{$150-180 \mathrm{~m}^{2}$} & Count & 47 & 27 & 28 & 22 & 16 & 140 \\
\hline & $\%$ & $33.6 \%$ & $19.3 \%$ & $20.0 \%$ & $15.7 \%$ & $11.4 \%$ & $100.0 \%$ \\
\hline \multirow{2}{*}{$180 \mathrm{~m}^{2}$ and above } & Count & 37 & 27 & 20 & 17 & 6 & 107 \\
\hline & $\%$ & $34.6 \%$ & $25.2 \%$ & $18.7 \%$ & $15.9 \%$ & $5.6 \%$ & $100.0 \%$ \\
\hline \multirow{2}{*}{ Total } & Count & 153 & 152 & 155 & 121 & 67 & 648 \\
\hline & $\%$ & $23.6 \%$ & $23.5 \%$ & $23.9 \%$ & $18.7 \%$ & $10.3 \%$ & $100.0 \%$ \\
\hline
\end{tabular}

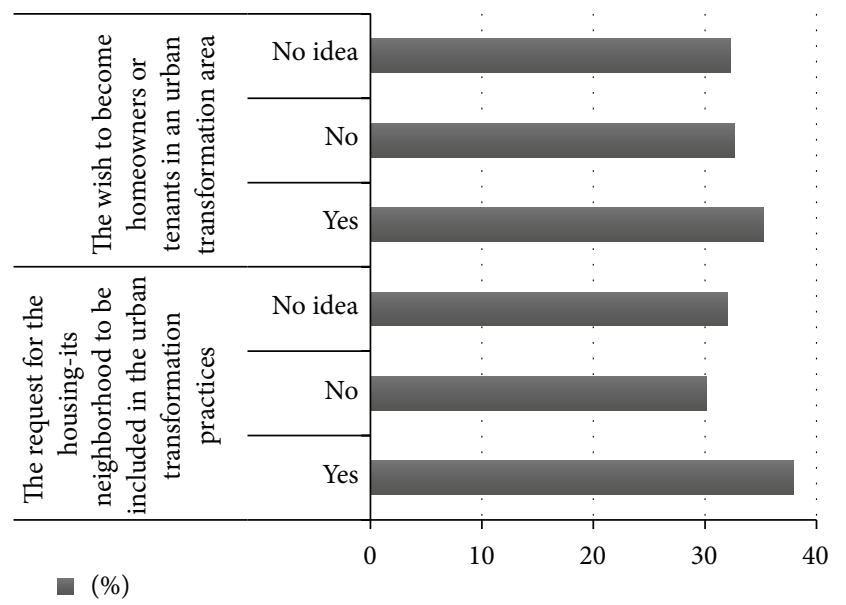

Figure 11: Comments on urban transformation.

According to the Pearson chi-square statistic, there is a significant relationship between the preferred housing size and age $\left(x^{2}(16)=34.931, P<0.05\right)$. This suggests that when organizing housing areas, needs of different age groups should be taken into consideration and housing units of various sizes should be designed accordingly.

Survey participants were also asked for their views on urban transformation practices. Nearly one-third of the respondents are in favor of their housing and its environment to be included in the scope of urban transformation, whereas a significant proportion of them stated they were against it, or they had no idea. Participants made similar comments as to whether they would like to be homeowners/tenants in the urban transformation area (Figure 11). Looking at it in terms of creating safe living spaces and quality of life, the public should be informed about urban transformation practices.

\section{Conclusion}

Factors regarding the housing and its immediate environment such as housing type, size, number of rooms, use of

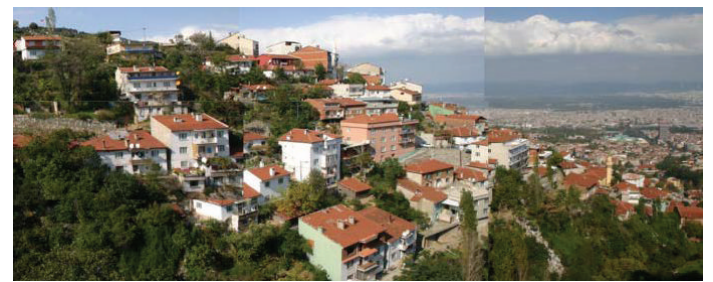

Figure 12: Alacahırka (Bursa Metropolitan Municipality Archives).

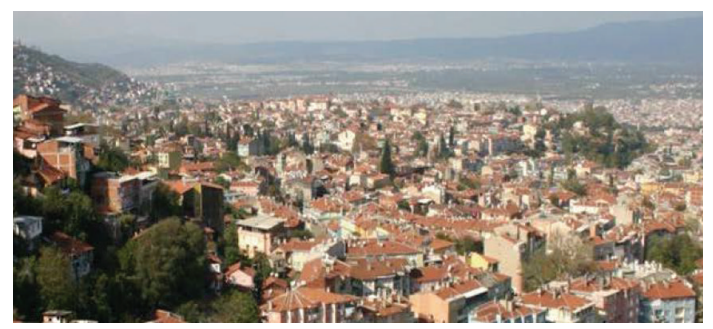

Figure 13: Pınarbaşı (Bursa Metropolitan Municipality Archives).

interior spaces, comfort features, features of immediate housing environment, adequacy of infrastructure, security, transportation, use of social infrastructure and open areas, social facilities, and neighbor relations are components that provide users with a high quality of life [36-38].

This study, which presents the necessary qualities of housing and its environment by considering physical and social needs of users, shows that, on the whole, the survey participants are satisfied with their housing units and housing environment. Most of the participants stated that they want to live together in their current area and within their current social interaction.

Spatial Features of the Housing. To ensure housing satisfaction, housing designs should be made based on users' sociodemographic and cultural structure. Spatial features of the housing, suitability of the spaces for usage, conveniences that are provided, and aesthetics of the building affect users' 


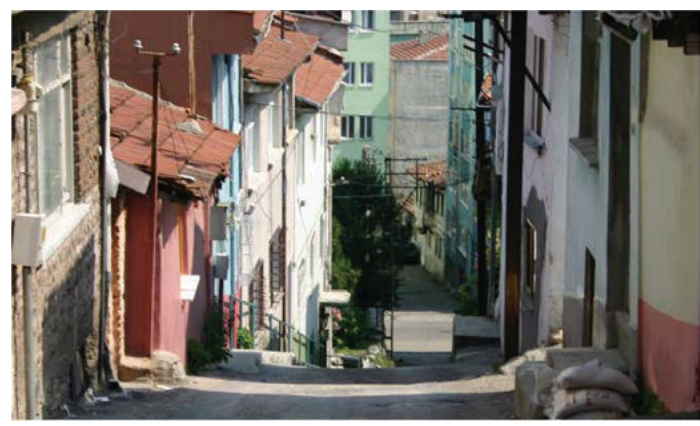

Figure 14: Meydancık-Hocataşkın (Bursa Metropolitan Municipality Archives).

perceptions positively or negatively, thus determining the quality of the housing unit. According to the survey data, noise and privacy are considered as significant problems about housing. Taking account of these problems and developing solutions in housing and environmental design will improve housing quality.

Features of Immediate Housing Environment. Facilities provided by the immediate housing environment and its features, an infrastructure without shortcomings, and municipal facilities improve the quality of life in the housing and housing environment.

Taking measures against disasters and creating safe areas on the scale of housing unit and settlement gain importance in the quality of life in the housing and housing environment. Providing transportation facilities for access to the city center and important facilities must be provided. Convenience in transportation positively affects the quality of the housing and housing environment.

Sociocultural Facilities Provided by the Settlement and Quality of Social Environment. Housing settlement plans should be made with regard to usage of gardens and open spaces that satisfy the needs of users of different age groups. Allowing for shopping facilities, health facilities, parks-green areas, school building, and religious facilities in settlement plans affects quality. Neighbor relations are considered important; therefore, buildings and the housing environment must be designed in a way that they will ensure the continuity of neighbor relations and further strengthen them. The continuity of life habits such as traditions and customs in the housing unit and housing environment is determined as a characteristic that strengthens social interaction.

To ensure life quality in the housing and housing environment, urban and environmental qualities should be improved; individuals should be safe; open spaces and sociocultural facilities should be provided; there should be a balance between housing density and population density in the settlement; there should not be any transportation problems in access from the housing to important facilities (school, workplace, etc.) and vice versa; transportation should be supported by public transport; social integration should be ensured; neighbor relations should be supported; and physical, social, and cultural sustainability of the settlement should be enabled.

Determining user needs and preferences that are suitable for local conditions and life styles primarily in housing production in urban transformation practices for renewal in disaster risk areas and in other urban transformation areas will improve housing quality and thus user satisfaction. As a result, users' adaptation to the new housing and housing environment after the urban transformation will be quicker.

\section{Conflict of Interests}

The authors declare that there is no conflict of interests regarding the publication of this paper.

\section{References}

[1] United Nations Department of Public Information, Agenda 21, Programme of Action for Sustainable Development. United Nations Conference on Environment and Development, 3-14 June 1992, Rio de Janeiro, Brazil, UN Department of Public Information, New York, NY, USA, 1993.

[2] E. Wiesenfeld and E. Sanchez, "Sustained participation: a community-based approach to addressing environmental problems," in Handbook of Environmental Psychology, R. B. Bechtel and A. Churchman, Eds., chapter 39, pp. 629-643, John Wiley \& Sons, New York, NY, USA, 2002.

[3] S. Wheeler and T. Beatley, "Urban sustainability at the city and regional scale," in The Sustainable Urban Development Reader, S. Wheeler and T. Beatley, Eds., pp. 450-451, Routledge, Abingdon, UK, 2004.

[4] M. Hugentobler and S. Gysi, "Sustainable urban development in Zurich-learning from successful projects," in City and Culture, Cultural Processes and Urban Sustainability, L. Nyström, Ed., pp. 306-320, Lenanders Tryckeri AB, Kalmar, Sweden, 1999.

[5] Institut Bruxellois pour la Gestion de l'Environnement, EcoCentre Project in Cureghem-Sustainable Development Project in the Urban Environment: From Planning to Action to the Integrated Eco-Quarter Project, IBGE-BIM, Brussels, Belgium, 2002.

[6] J. Kenworthy, "Building more liveable cities by overcoming automobile dependence: an international comparative review," in Sustaining Human Settlement. A Challenge for the New Millennium, R. Lawrence, Ed., pp. 271-311, Urban International Press, North Shields, UK, 2000.

[7] B. Furze, T. de Lacy, and J. Brickhead, Culture, Conservation and Biodiversity, John Wiley \& Sons, Chichester, UK, 1996.

[8] D. Özdemir, "Process management and participation in the transformation of culture and tourism: Temple Bar, Dublin," in Politics, Legislation, and Application in Urban Transformation: European Experience, Applications in İstanbul, D. Özdemir, Ed., pp. 174-191, Nobel Publication, Ankara, Istanbul, 2010.

[9] A. F. Göksu, Innovative Approaches in Urban Transformation Projects. Urban Transformation Symposium, 11-13 June 2003, UCTEA Chamber of City Planners, İstanbul, Turkey, 2003.

[10] P. P. Özden, Urban Renewal, İmge, Ankara, Turkey, 2008.

[11] D. Oktay, "An overview of the theoretical framework of urban design: our cities, quality of life, and sustainability," Mimarlik, Chamber of Architects of Turkey, vol. 302, pp. 45-49, 2001. 
[12] Habitat II Turkey's National Report and Action Plan, Turkey's National Report and Action Plan, The World Summit on Cities, 1996.

[13] Report on Housing Problems and Housing Need in Turkey, 2013, (Turkish), http://www.imo.org.tr/resimler/dosya_ekler/ 9ca6617c167713d_ek.pdf.

[14] R. Marans, "Measuring quality of urban life," Mimarlı: Chamber of Architecs of Turkey, vol. 335, pp. 28-31, 2007 (Turkish).

[15] H. D. Türkoğlu, F. Bölen, K. P. Baran, and R. W. Marans, "Measuring quality of life in residential areas in İstanbul," Mimarlik, Chamber of Architecs of Turkey, vol. 335, pp. 32-36, 2007.

[16] Y.-J. Lee, "Subjective quality of life measurement in Taipei," Building and Environment, vol. 43, no. 7, pp. 1205-1215, 2008.

[17] D. C. C. K. Kowaltowski, V. G. da Silva, S. A. M. G. Pina, L. C. Labaki, R. C. Ruschel, and D. de Carvalho Moreira, "Quality of life and sustainability issues as seen by the population of low-income housing in the region of Campinas, Brazil," Habitat International, vol. 30, no. 4, pp. 1100-1114, 2006.

[18] G. M. Ricardo, L. U. J. David, R. Eulogio, and R. José, "Housing, space and quality of life: introduction," in Housing, Space and Quality of Life, R. García-Mira, D. L. Uzzell, J. E. Real, and J. Romay, Eds., chapter 1, pp. 1-5, Ashgate, England, UK, 2005.

[19] R. J. Lawrence, "Healty residential environments," in Handbook of Environmental Psychology, R. B. Bechtel and A. Churchman, Eds., chapter 26, pp. 394-412, John Wiley \& Sons, New York, NY, USA, 2002.

[20] R. Djebarni and A. Al-Abed, "Satisfaction level with neighbourhoods in low income Public Housing in Yemen," Property Management, vol. 18, no. 4, pp. 230-242, 2000.

[21] H. Y. Park, "Housing welfare indicators for the quality of life in Korea," Housing Studies Review, vol. 14, no. 1, pp. 5-26, 2006.

[22] G. Meng and G. B. Hall, "Assessing housing quality in metropolitan Lima, Peru," Journal of Housing and the Built Environment, vol. 21, no. 4, pp. 413-439, 2006.

[23] M. A. Mohit, M. Ibrahim, and Y. R. Rashid, "Assessment of residential satisfaction in newly designed public low-cost housing in Kuala Lumpur, Malaysia," Habitat International, vol. 34, no. 1, pp. 18-27, 2010.

[24] V. J. Ettinger, Towards a Habitable World, Elsevier, Amsterdam, The Netherlands, 1960.

[25] A. Özbilen, A Study on the Objective Quality of Structure in Turkey, no. 4-5, İTÜ Faculty of Architecture, Building Research Institute, Range C: Researches, Istanbul, Turkey, 1967 (Turkish).

[26] T. Teck-Hong, "Housing satisfaction in medium- and high-cost housing: the case of Greater Kuala Lumpur, Malaysia," Habitat International, vol. 36, no. 1, pp. 108-116, 2012.

[27] A. G. Salleh, "Neighbourhood factors in private low-cost housing in Malaysia," Habitat International, vol. 32, no. 4, pp. 485493, 2008.

[28] A. D. Jiboye, "Post-occupancy evaluation of residential satisfaction in Lagos, Nigeria: feedback for residential improvement," Frontiers of Architectural Research, vol. 1, no. 3, pp. 236-243, 2012.

[29] O. M. Ukoha and J. O. Beamish, "Assessment of residents' satisfaction with public housing in Abuja, Nigeria," Habitat International, vol. 21, no. 4, pp. 445-460, 1997.

[30] S. H. Cho and T. K. Lee, "A study on building sustainable communities in high-rise and high-density apartments-focused on living program," Building and Environment, vol. 46, no. 7, pp. 1428-1435, 2011.
[31] M. A. Mohit and M. Azim, "Assessment of residential satisfaction with public housing in Hulhumale, Maldives," ProcediaSocial and Behavioral Sciences, vol. 50, pp. 756-770, 2012.

[32] S. Ayata and A. G. Ayata, Housing, Neighborhood, and Urban Culture, Index of Housing Research-10, Başbakanlık Housing Development Administration of Turkey, 1996, (Turkish).

[33] H. D. Türkoğlu, F. Bölen, K. P. Baran, and R. W. Marans, "Measuring quality of life in İstanbul," itüdergisi: a Architecture, Planing, Design, vol. 7, no. 2, pp. 103-113, 2008.

[34] Y. Dülgeroğlu, S. Aydınlı, and G. Pulat, “The problem of quality in mass housing," in Index of Housing Research-4, vol. 1-2, pp. 261-271, Housing Development Administration of Turkey, 1996 (Turkish).

[35] E. O. İmamoğlu and V. İmamoğlu, "Human, home, and its environment: a research on mass housing in Ankara," Housing Development Administration of Turkey, Index of Housing Research, vol. 15, p. 105, 1996 (Turkish).

[36] G. F. M. Fernandez, F. R. Perez, and J. M. R. Abuin, "Components of the residential environment and Socio-demographic characteristics of the elderly," Journal of Housing for the Elderly, vol. 18, no. 1, pp. 25-49, 2003.

[37] L. Max, "Determinants of residential satisfaction: ordered logit versus regression models," Growth and Change, vol. 30, no. 2, pp. 264-287, 1999.

[38] H. D. Türkoğlu, "Residents' satisfaction of housing environments: the case of Istanbul, Turkey," Landscape and Urban Planning, vol. 39, no. 1, pp. 55-67, 1997. 

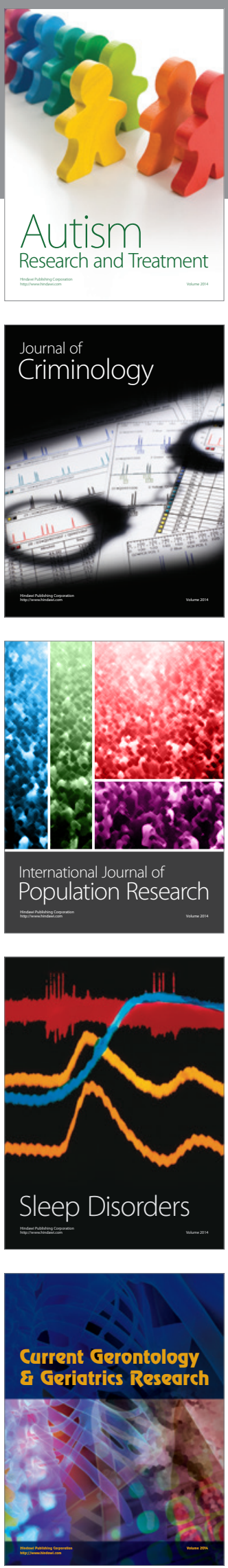
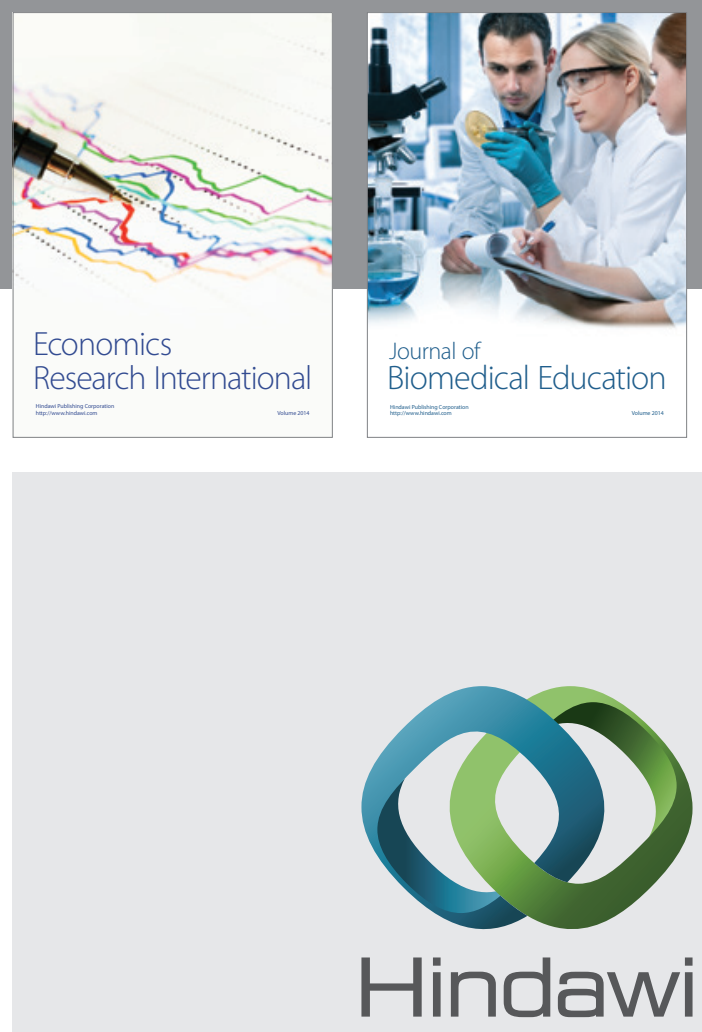

Submit your manuscripts at

http://www.hindawi.com
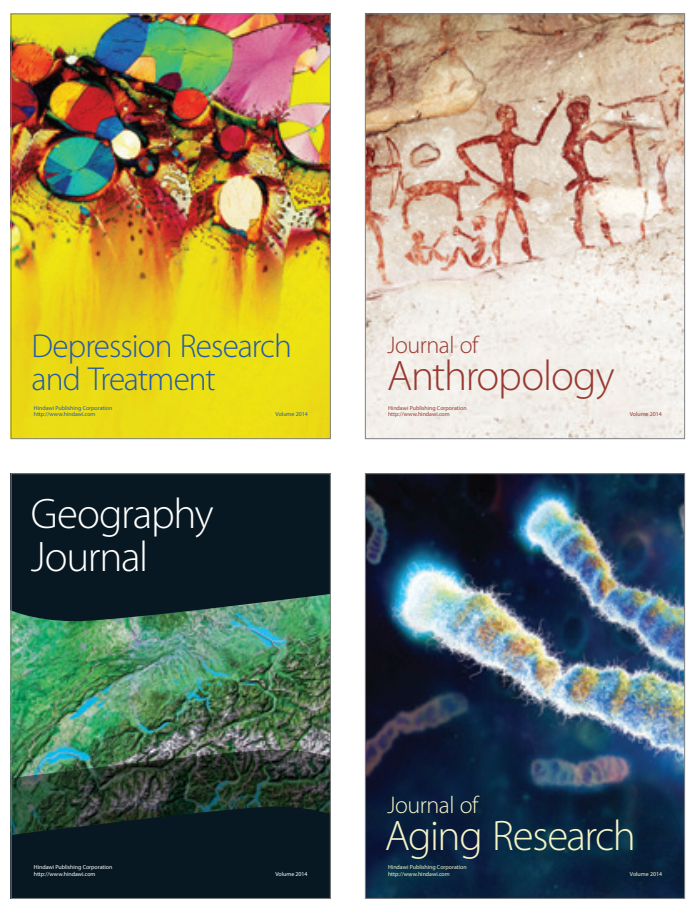
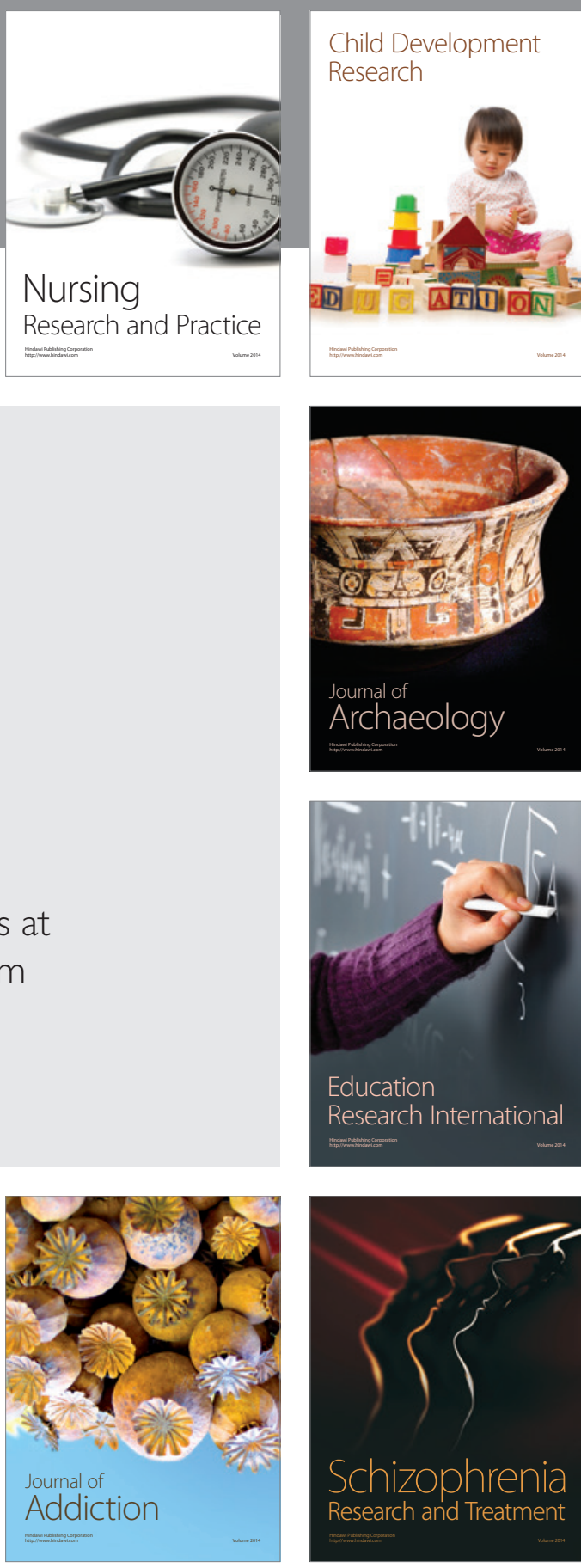

(D)
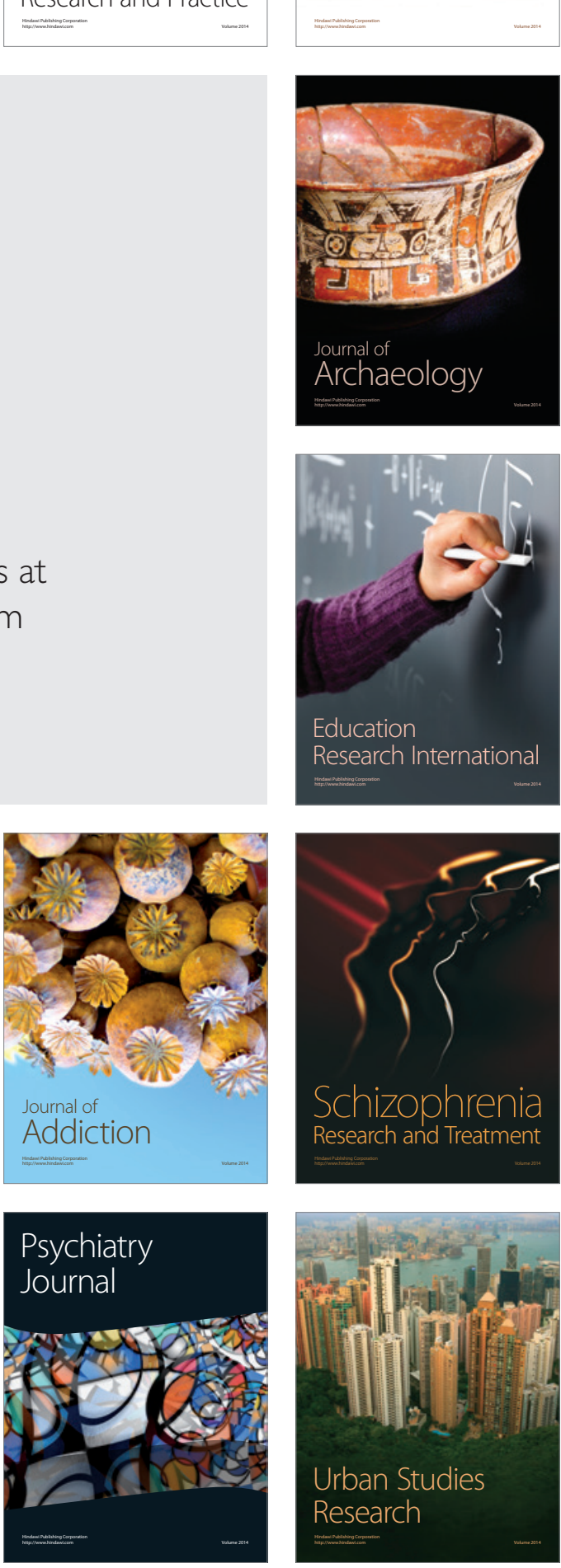